\title{
Experiencing the Covid-19 Outbreak Socially: On Some Recent Philosophical Contributions
}

\author{
Sergio Alloggio \\ https://orcid.org/0000-0002-7273-3954 \\ University of Pretoria \\ sergioalloggio@gmail.com
}

\begin{abstract}
The coronavirus outbreak is currently scrutinised by professional philosophers from different traditions and geographical areas. By focusing on several contributions from European academic philosophers, this article assesses whether such philosophical works manifest and reproduce, consciously or unconsciously, neocolonial and Eurocentric understandings of the Covid-19 pandemic. Particular attention will be given to Agamben's and Žižek's interpretations to show the role played in their analysis by reductionist and regressive constructions of the social world. I will then draw on several contributions from African and Africana philosophers (Gqola, Asante, More, West and Outlaw), to set up a theoretical space in which the social experiencing of the coronavirus outbreak, as well as the self-understanding of academic philosophers, could be positively reconceptualised. This act of resignification has its aim in promoting adequate forms of institutional analysis and professional engagement, and it points to the emancipatory task philosophy embodies in the global South.
\end{abstract}

Keywords: Covid-19; Eurocentrism; neocolonialism; Agamben; Žižek; Africana philosophy; African philosophy

Racism, colonialism, imperialism and slavery, to which Africans and people of African descent were subjected, have not been eradicated. Instead they have taken on new forms: neo-slavery, neoimperialism, neocolonialism and the new racism. The recognition that this undignified treatment is continuing by other means, added to the fact of a constantly shrinking global space, necessitates the strategic importance of a unified front and a resolve to work together, collectively as Africans and Africans in diaspora and, therefore, to develop an Africana philosophy that would interrogate and challenge the assumptions constitutive of Western philosophical thinking in relation to Africans and people of African descent. (More 2002, 76)

\section{UNISA $\cong$}




\section{Alloggio}

Scientists have the task of collecting and elaborating data about the Covid-19 pandemic in order to create effective vaccines against it; artists have the mandate of being aesthetically struck by the viral atmosphere and producing innovative artistic creations in response to it; while we, professional philosophers - and especially those among us who belong to the progressive side of our discipline - ought to theorise about the current social emergency related to the coronavirus outbreak and, possibly, use it as a theoretical lever to promote transformative analyses and engagements within the broader emancipatory project of African philosophy.

We are living in a time, and supposed to be philosophically thinking, teaching, and writing, in which Thanatos - in the form of the Covid-19 virus - is dominating at almost every aerial (and material) level. ${ }^{1}$ On the one hand, we can and should debate the extent to which the coronavirus pandemic is affecting our own ethical or political selfunderstandings; on the other hand, the virus is working at a more structural level, with its death drive massively functioning within microscopic forces, eating up the life drive not only through molecular interaction: but the parasitic drive-tension carried by the virus is also virtually colonising all aspects of one's psychic life. Therefore, I think we should employ an intersectional analytic to understand and address how the current medical emergency is worsening the social dimension of all those different labels contained in what is currently known as intersectionality (race, sex and gender, class, age, ableism, psychic status, and so forth). In what follows, I am going to focus on how the Covid-19 pandemic has been reductively analysed by several professional philosophers from the global North, assessing the Eurocentric, regressive aspects of their interpretations and, through such criticism, I shall explore some of the dialectical tensions at play when we philosophically theorise on the (social experiencing of the) ongoing coronavirus emergency.

Two academic philosophers have surreptitiously compared the excessive response to the Covid-19 emergency to other global pandemics such as, for instance, scepsis. But, first, scepsis is not caused by a virus and it is not, more importantly, a contagious disease; that is, it cannot be transmitted through any air or solid medium, as is the coronavirus. Such comparison, when assumed as starting argument and subsequently coupled with liberal assumptions and strict analytic orientation, betrays recurring reductions and logocentric determinations, especially if these preconceptions occur in a philosophical discussion supposedly unmasking "reasoning biases," "inconsistency," and "adequacy of evidence" pertaining to the "orthodox Covid-19 narrative" (Kidd and Ratcliffe 2020). It should also be noted that the actual World Health Organisation's Global Report on Scepsis (WHO 2020), which the shorter WHO news release quoted by Kidd and Ratcliffe refers to, strongly emphasises how both scepsis and its related death rate are endemic in low-income households and nations: this could have led them to a different approach in their analogy, since they exclusively rely on poor media

1 Irigaray (1999) has extensively analysed how repressed aerial elements affect the construction of patriarchal motives in Western philosophy, how they continuously haunt the construction of our discipline. 
coverage for scepsis in the United Kingdom. However, the main argument suggested by Kidd and Ratcliffe is that the coronavirus outbreak has substantially altered "many people's sense of how things are with the world. It is no longer homely in the way it was. Everything is shrouded in danger and distrust. A world that was once a theatre of possibilities is now suffused with an air of dread," and this change, they argue, has unfortunately promoted a "widespread decontextualisation" of the pandemic in terms of traditional judgments and "proportionality." It could be counterargued that for centuries the vast majority of people (women, Blacks, proletarians, and so forth) has been experiencing the (social) world in those exact terms. The receiving end of (neo)colonialism, patriarchy, and imperialism, to name but a few, has never been part of those unfortunately now suspended "accepted norms" the two professional philosophers lament about. For instance, Black women's lives in the world are constantly brutalised by "accepted norms" through gender-based violence, cumulative trauma, and "a crisis of meaning" that make it hard to look back with regret on any preCovid-19 linearity. If traditional (Anglo-Saxon) epistemology assumes uncritical notions such as belief, judgment, and self-consciousness as produced and received by an ahistorical philosophical ego, if such essential components of one's interiority are discussed without taking into account the genetic and historical role of structural violence, male domination, and material deprivation in shaping one's interiority, then (Black) women can hardly ground their epistemic core on notions that are intrinsically deaf and blind to their "defiled, rejected and forgotten" histories (Gqola 2009, 73). In her works, Pumla Dineo Gqola, a prominent South African feminist, intersectionally deconstructs dominant and toxic narratives of the social world, showing how such narratives constantly reinforce violent conceptions of masculinity in postcolonial contexts. It would be important to question where, for instance, women would have ever found these "spaces of safety" (Gqola 2016, 71), to question whether an analysis of psychic processes based on the canonical work of William James and Ludwig Wittgenstein, as suggested by Kidd and Ratcliffe, can adequately highlight how "meanings have material effects that are racialised, economic, gendered and spatially designated" (Gqola 2009, 64). What is at stake here is a philosophical account that is able to account for violent, contradictory, and ambivalent practices that foreclose (women's) interiority. A philosophical account, which understands how the very same inner space invested with libidinal nostalgia by Kidd and Ratcliffe, has hardly been "a place of psychic safety" (Gqola 2009a, 4) for those who have been forced to daily experience dread, decontextualisation, danger, and distrust long before any physical restriction was implemented.

Giorgio Agamben, a prominent Italian philosopher, reads the current response to the Covid-19 epidemic as an embodiment of modern Western history, as biopolitics at its best (Agamben 2020, 13 and 40). ${ }^{2}$ Agamben (1998), who understands modern history as the progressive unfolding of Foucault's paradigm of securitisation, no longer sees the

2 Most of Agamben's short pieces contained in this book have been translated into English and other languages (Agamben 2020a). 


\section{Alloggio}

"state of exception" and "bare life" as accidental dimensions occurring in specific historical moments (as in World War II or totalitarian regimes). The normalisation of both the state of exception and bare life in contemporary democracies epitomises for Agamben a structural change within the power/knowledge nexus, whose functioning now takes place and affects, first and foremost, how the state produces and manipulates its citizens' biological dimensions to subtly dominate them-this is, in short, how biopolitics operates nowadays.

In the early months of 2020, Agamben hinted at the nonexistence of "an alleged epidemic" (Agamben 2020, 17; Agamben 2020b). I shall not discuss this statement here, for he seems to have accepted the reality of the pandemic in his more recent interventions. Rather, I would like to focus on how Agamben, while constructing his paradigm of biosecurity in relation to the coronavirus outbreak, draws on Eurocentric assumptions and how these deeply impact on his professional self-understanding as professional philosopher. In his discussions of the Covid-19 emergency, biosecurity is assumed to be the most efficient form of biopolitics in the West because, according to Agamben, modern history equates with biopolitics (Agamben 2020, 83 and 41; Agamben 2020c). While biopolitics tries to exert mass control through state sovereignty, biosecurity draws on more effective forms of domination such as technological militarisation and sanitary despotism. What should be noted, however, is the way Agamben characterises Western modernity as grounded on three main beliefsystems ("Christianity, capitalism and science") without mentioning the crucial role they played in the creation and implementation of colonialism and a global slavemarket, how these three belief-systems justified and promoted colonial rule and structural racism (Agamben 2020, 69; Agamben 2020d). The Argentinian philosopher Walter Mignolo, writing in defence of the global South, has poignantly analysed the ways in which continental philosophy "deliberately ignores" the "geopolitics of knowing," thus producing an "epistemic colonial difference" which dehumanises who falls outside its supposedly universal claims, and who dares to survive outside its regional borders and conceptual boundaries (Mignolo 2017). Agamben's philosophical diagnosis is based on the material and epistemic erasure of what contributed to the economic and philosophical universalisation of Europe. Such erasure is still active in Eurocentric attacks on European genealogy such as Agamben's, because what remains unscathed in these critical gestures is the uncontested hegemonic "image of totality that Eurocentrism projects" (Mignolo 2017, 293). ${ }^{3}$ Ultimately, what Agamben represents and symbolises is a traditional position within the history of continental philosophy, a position which validates its own critical genealogy while constantly naturalising its disciplinary privilege through forms of narcissistic self-understanding.

In Agamben's conceptual framework, every aspect of the Covid-19 pandemic is immediately read, assumed, and incorporated to confirm his general philosophical

3 To see how uncontested forms of European hegemony function in Agamben's philosophy, see for instance Agamben (1998, 36-38 and 176-180). 


\section{Alloggio}

diagnosis: every aspect gets interpreted, he writes, "as symptoms and signs of a broader experiment - as any serious political analysis would require - in which what is at stake is a new paradigm for the governance of men and things" (Agamben 2020, 76; Agamben 2020e). The Italian philosopher writes as if this were absolutely true, as if the social response to the coronavirus pandemic represented an uncontestably historical confirmation of his own philosophy; but the social world outside his ego, civil society, and its members think otherwise, thereby causing a deep narcissistic wound to his own philosophical unconscious. ${ }^{4}$ Much of Agamben's interventions are lamentations about the sacral role scientists and virologists are playing in the pandemic, and much of his arguments betray professional and existential envy about the fact that the (Western) Philosopher is no longer counselling the King, particularly now in a time of emergency, and especially at a time in which the Covid-19 epidemic has purportedly been confirming his (Holy) Logos. In fact, Agamben desperately addresses other experts from religious, economic, and judicial powers in an attempt to curb the Scientist's public success - but he asks for support from the very same powers he sees behind the biopolitical catastrophe (Agamben 2020, 42 and 50-51; Agamben 2020c; Agamben 2020f). Not surprisingly, when Agamben is supposed to promote collective resistance against the biosecurity Leviathan, when it is time to call for counterhegemonic response against the fatal mechanisms of sanitary terrorism, the legacy of his Heideggerian and Foucauldian roots becomes fully evident: the Agambenian solution lies in an empty "politics to come" as well as "bearing witness" to unspecified concepts of truth and linguistic lucidity (Agamben 2020, 95, 75, 89; Agamben 2020d). However, the only one time he is actually advocating for real, concrete action, as he does against distant learning, he argues that university professors should resign and students stop enrolling as a form of passionate resistance (Agamben 2020, 101; Agamben 2020g). But these are aristocratic forms of rebellion, for only wealthy members of society can afford to voluntarily lose their job or tertiary education, and, ultimately, such forms of philosophical rebellion are perfectly in line with Agamben's elitism and acutely reflect the extent to which he is entangled by the charms of his oracular philosophy.

The book Pandemic! recently published by the Slovenian philosopher Slavoj Žižek, centres around the question of what we should philosophically learn from the ongoing Covid-19 pandemic. His recurring answer is that the structural wrongs of global capitalism must be corrected by returning to "some kind of reinvented communism" (Žižek 2020, 70). Throughout the book, such reimagined form takes many names, from "enforced socialism" to "philosophical revolution"; from "war communism" to "disaster communism." Although Žižek puts his initial emphasis on the philosophical work needed to "analyze in detail the social conditions that made the coronavirus possible" (Žižek 2020, 13), it is what counts as details and social conditions that makes his "reinvented communism" sentimental, utopian, and, ultimately, deeply problematic.

4 On the necessary acknowledgment, recognition, and genuine philosophical dialogue with the sexed other and other historically-excluded subjects, who are never mentioned by Agamben in his interventions, see Irigaray (1993), especially the two sections "Love of Self" and "Love of Same, Love of Other." 
On a geopolitical level, Communist China is constantly attacked for lack of transparency, authoritarian control, and ideological censorship on its people-Žižek indirectly hopes that the pandemic could somehow "lead to the fall of Communist rule in China" (Žižek 2020, 39). Russia and Turkey are also on the bad side of the geopolitical landscape: the Slovenian Lacano-Marxist describes Russian and Turkish involvement in the Syrian conflict as criminal, portraying both countries to be also aiming at the dissolution of United Europe. Žižek's omission of the role played by the Western military coalition in sparking the Syrian conflict in 2014, a conflict whose main goal is the attempt to contain the Russian sphere of influence in the Middle East; his lack of understanding of the essential role Russia and China are contradictorily playing to shift the geopolitical balance of power from a unipolar system (in which Western neoimperialism has no rival), to a more distributed and stable multipolarism; and given his silence on the immense fall of the poverty rate in China over the last four decadesan unmatched decline in recent history-, one has to wonder whether Žižek's implicit affiliation to the North Atlantic field of power overdetermines, in the last instance, his communist analysis of international relations.

However, Žižek manifests his bigger concern when he discusses how the middle-class's symptomatology has been exacerbated by forced confinement. What philosophically worries him in almost every chapter of his book is the sudden lifestyle decline for the white, globalised Western bourgeoisie - which is his primary audience. In fact, he is relentlessly writing to comfort this transnational class (he belongs to) from experiencing too much alienation and class-anxiety, as we read in the book's final argument: "pretend the lockdown is just a game ... gladly succumb to all your guilty pleasures" (Žižek 2020, 112-113). Not surprisingly, then, much of his philosophical reflections is grounded on ethical prescriptions, forms of privileged solidarity, and existentialist reminders about the lack of meaning in human life, a sort of sentimental communism constantly bordering on ritualised adages from self-help guides.

A similar approach is working in Žižek's most original interpretation of the coronavirus pandemic, which could be named "the same boat argument." A structural aspect of the Covid-19 outbreak is that all countries are affected by it and, since everyone, despite their class position, could potentially be infected, such awareness should politically unite peoples on a global scale and then push for unprecedented forms of solidarity and cooperation: Žižek often reminds us that "we are now all in the same boat" (Žižek 2020, 31 and 42). ${ }^{5}$ However, a specific people in a particular boat could apparently sink faster than others, a determinate boat is currently experiencing worse weather conditions that others, and this boat is, according to Žižek, none other than Europe. Several aspects concur to endanger the European vessel sailing in the pandemic sea, namely, physical restrictions, economic impact, populist disruptions, and migrant crises. None of these aspects is exclusively European but, somehow, they seem to put European nations in a worse situation than, for instance, sub-Saharan or Latin American countries. If such

Žižek traces back on page 15 the origin of such metaphor to Martin Luther King. 
analytic level is coupled with the Žižekian refusal to structurally account for "European racism and colonization" (Žižek 2020, 36) as the primary cause for migrants dramatically flooding into Europe from "poorer nation[s]"; we can argue that the Slovenia philosopher, in privileging Europe and its epistemic supremacy, is articulating the kind of Eurocentric self-assuring understanding of the pandemic required by one of its intellectual heirs. Žižek's ambivalent position, by which he first mentions the need for stronger actions to overcome European neocolonialism, and his subsequent silence and refusal to structurally engage with the racial problematic throughout the book, reproduces a traditional gesture quite common in white Marxism every time racism and colonialism come to the fore. ${ }^{6}$ The Covid- 19 pandemic does not equally affect everyone, despite their race, sex, class, age, nationality, psychic status or education, and many other conditions ought to be added to the list. More specifically, it would be hard to jump on and enjoy the Žižekian boat for those who do not share and benefit from the same power differentials as bourgeois Europeans do, and this is that which determines, ultimately, the neocolonial stance of his boat metaphorics. What is wrong with Žižek's upgraded version of the "same boat argument" it is not that a European (philosopher) is discussing new ways to unifying Europeans and progressively fixing European problems; what is irremediably regressive and utterly aberrant is the white supremacist logic this task is predicated upon, with the corollary erasure, denegation, and foreclosure of a European colonial past and its current resurgence inside and outside its borders. Žižek's philosophical position is not wrong in itself-what is problematic is that its Eurocentrism is grounded on unjust world relations still embedded in neocolonial attitudes. A genuine awareness of the intersectional differentials at play in the asymmetric experiencing of the pandemic, with its unbalanced social composition and unequal material consequences, should have taken Zizek beyond the recurring ethicoexistentialist prescriptions at work in the philosophical economy of his arguments; it could have led him, at least in part, beyond his conservative misappropriation and regressive misutilisation of "the same boat argument" in relation to unjust Eurocentric solutions of the Covid-19 pandemic.

There is, nonetheless, another troubling aspect in Žižek's book, namely his philosophical inability to transform the social dimension of coronavirus, of any mass viral infection, into a revolutionary signifier. What remained unthought in his project is the symbolic relationship that could have been established between the Covid-19 virus and both white supremacist logic and capital self-valorisation. After giving us a brief account of what viruses are and how they operate, he discusses "the mystery of viruses" in his own terms. Here is how his analysis unfolds:

6 West $(1988,18)$ explains: "the time has passed when the so-called race question, or Negro question, can be relegated to secondary or tertiary theoretical significance in bourgeois or Marxist discourses. Instead, to take seriously the multileveled oppression of African peoples is to raise crucial questions regarding the conditions for the possibility of the modern West, the nature of European conceptions of rationality, and even the limited character of Marxist formulations of counterhegemonic projects against multileveled oppression." 


\begin{abstract}
Alloggio
This oscillation between life and death is crucial: viruses are neither alive nor dead in the usual sense of these terms, they are a kind of living dead. A virus is alive in its drive to replicate, but it is a kind of zero-level life, a biological caricature not so much of death-drive as of life at its most stupid level of repetition and multiplication. However, viruses are not the elementary form of life out of which more complex developed; they are purely parasitic, they replicate themselves through infecting more developed organisms (when a virus infects us, humans, we simply serve as its copying mechanism) ... and continues to haunt (infect) them, a reminder that cannot ever be reintegrated into the subordinate moment of a higher level of life. (Žižek 2020, 78-79)
\end{abstract}

It is here, at this argumentative crossroad, at this theoretical juncture in the philosophical economy of his argumentation, that Žižek could have dialectically moved from an uncomplicated (psychoanalytic) account of viruses, to antagonistic and transformative metaphorical identifications between viruses, white supremacist logic and, ultimately, capital self-valorisation. Instead of detecting and applying the progressive force of such resignification, the Slovenian philosopher immediately compares biological viruses to, first, Hegel's Geist and then to Dawkins's memes and Tolstoy's speculations. ${ }^{7}$ What is more troubling is that Žižek is supposed to be fully aware of how Karl Marx, in an effort to structurally account for their parasitic forms of exploitative behaviour and selfvalorising nature, characterises capitalists and capital as "vampire-like" beings. ${ }^{8}$ Even though the terminology he decides to employ in describing how viruses actually work terribly resembles Marx's metaphorics of vampirism, even if he fully masters Western Marxism's vocabulary, Žižek symptomatically addresses the "mystery of viruses" only in psycho-biological, cultural, and traditional philosophical terms: in the constant act of naturalising the social perception of mass viral infections, he is also ideologically neutralising the counterhegemonic potential concealed in such discursive praxis.

If the recurring question, among professional philosophers, about what we should learn from the Covid-19 outbreak usually finds regressive answers in Eurocentric reassurances for the global North bourgeoisie, part of the emancipatory task of producing analyses, narratives, and discourses to describe the ongoing pandemic - as

7 Žižek (2020, 79-81): “[O]ur example should be 'Spirit is a virus.' Human spirit is a kind of virus that parasitizes on the human animal, exploits it for its own self-reproduction, and sometimes threatens to destroy it ... memes are 'viruses of the mind', parasitic entities which 'colonize' human might, using it as a means to multiply themselves. Perhaps, however, the time has come to fully rehabilitate Tolstoy, his unique theory of art and man in general, in which we find echoes of Dawkins's notion of memes... The basic category of Tolstoy's anthropology is infection: a human subject is a passive empty medium infected by affect-laden cultural elements which, like contagious bacilli, spread from one to another individual. And Tolstoy goes here to the end: he does not oppose a true spiritual autonomy to this spreading of affective infections; he does not propose a heroic vision of educating oneself into a mature autonomous ethical subject by way of getting rid of the infectious bacilli."

8 While Neocleous (2003) focuses on Marx's recurring vampiric metaphors to exemplify the horrific dynamics which capitalists represent, MacLellan (2013) transcends Neocleous's analogic framework and connects the role played by Marx's gothic metaphorics not only to how living labour and workers are vampirised by capitalists but, most importantly, to the structural way capital constitutively answers to vampiric forms of self-reproduction and self-valorisation. 
well as those collective dynamics it relies on and reproduces - should rather aim at showing how a transformed coronavirus lexicon could be a legitimate tool to fight against a dominant class, parasitically replicating its neocolonial genome inside and outside our disciplinary and institutional bodies. The first step for such transformative resignification is to immunise us, through decolonial vaccination, against the white racial supremacy virus at work in the naturalisation of the coronavirus pandemic. Molefi Kete Asante stresses the visible role Afrocentrism must play in "choices, language, explanations, definitions, actions, and values" to genuinely recentre personal, disciplinary, and societal praxis against the ideological traps of Western hegemony (Asante 2017, 234). Asante's approach epitomises how the structural reconfiguration of professional philosophical practice must always start with a positive act of Africanist introjection, if we want to properly understand and adequately carry forward the emancipatory potential of African philosophy.

In similar terms, though moving to more concrete and determinate aspects, the South African philosopher Mabogo Percy More warns us against the dangers of internalising white neoliberal forms of solidarity when it comes to opposing structural oppression with collective actions and progressive projects (More 2009). He explains that an atomised seriality of liberal agents gets transformed into group solidarity whenever "a common interest, a collective and shared apprehension of a common project, a common transcendent end, and a common destiny" are experienced as "reciprocal relations" (More 2009, 27). Therefore, racial oppression calls for emancipatory group solidarity grounded on the awareness that, since racism primarily operates at a collective level, which is at the same time epistemic, economic, and socio-political, a liberal conception of autonomous agents immediately delegitimises any historical "determination of the victims of racist oppression to defend themselves," an act of epistemic delegitimation happening every time material responses against racism go beyond individual actions (More 2009, 38). Both Asante and More highlight how the Afrocentric structural fight against white supremacy has to be rethought through independent African perspectives and practices. The same need for Afrocentric reconceptualisations should orientate questions and approaches pertaining to our discipline and its institutional reproduction.

In his original combination of critical race theory and Marxism, Cornel West criticises not only Western Marxism's hermeneutical limits in understanding the racial problematic, but he also genealogically unearths reductionist approaches in Marxist historiography, showing how "monodeterminism or subtle multideterminist causal relations" invariably make class status eclipse all other statuses (West 1988, 18-21). West, a leading Afro-American thinker whose very work manifests how the critical legacies of European Marxism could still be valuable for Africana philosophy, in addition to poignantly transcending such inadequate approaches, gives us three interconnected levels of inquiry (genealogical, microinstitutional, and macrostructural) to understand and dismantle "the specificity of the European oppression of African peoples at the level of methodology" (West 1988, 22). Here I would like to emphasise how West's second microinstitutional analytic level could be fruitfully employed to 


\section{Alloggio}

study how philosophical knowledge gets neocolonially replicated in our university departments. Microinstitutional analysis primarily focuses on "the articulation of the white supremacist logics within the everyday lives of Africans in particular historical contexts. It focuses on the effects upon African peoples of the binary oppositions of true/false, good/evil, pure/impure within the white supremacist logics" (West 1988, 23). More specifically, it would be important to use, in studying South African professional philosophy, the microinstitutional moment as a "probe into forms of European subjugation of African peoples," thus showing "how the various white supremacist logics shape African self-identities, influence psychosexual sensibilities, and help set the context for distinctive Afro-American cultural styles, linguistic gestures, and modes of resistance" (West 1988, 23).

In a similar theoretical gesture, Lucius T. Outlaw (Jr.) has recently depicted the historiographical emergence of Africana philosophy, with the relative transformation of academic philosophy from being "a handmaiden to racialized imperialist colonialism, enslavement, and genocide," to an emancipatory discipline with its distinctive general features, autonomous relevance, specific institutional developments, and diverse demographics (Outlaw 2017, 246). ${ }^{9}$ The US philosopher explains how such institutional emergence was critically dependent on "revisions, in some cases rather radical, on how practitioners of professionalized academic philosophy were trained to conceive of the discipline in terms of its subject matters, methods, criteria of veracity, curricula, the discipline's origins and histories, and, ultimately, the origins and histories of white peoples and their accomplishments" (Outlaw 2017, 248). If this shift is to produce a fundamental change in "professional, personal and, social identifications" amongst white scholars, as Outlaw does hope, it is because we are called to radically change the perception of what we white practitioners of philosophy are, as well as our role within past, present, and future disciplinary histories - we are called to radically desublimate our "substantial investments in whiteness" (Outlaw 2017, 248). To know and positively be part of African and Africana philosophy, to know and progressively be part of many local, institutional, and historical struggles to genuinely decolonise and fully liberate our discipline from neocolonialism, has an immense pedagogical value. We are constantly called, Outlaw explains, to "enlarge and strengthen shared understandings as philosophers and, thereby, to enlarge, appropriately, the scope and content of the field" (Outlaw 2017, 262). Outlaw's philosophy, with its final position in the short narrative of disciplinary maturation I have briefly outlined here, represents not only transitional and much needed historiographical rearrangements of our academic self-image, but his scholarly contributions are also dialectical examples of critical commitment to both deconstructive and reconstructive struggles for the very progress of that image.

This article is an attempt at understanding our social experiencing of the Covid-19 pandemic Afrocentrically. It is an attempt at reading the coronavirus as a metaphorical

9 For a more detailed genealogical investigation of African philosophy, Africana philosophy, and the disciplinary challenges they have been facing within contemporary academic philosophy, see Outlaw (1996). 


\section{Alloggio}

plexus of (unbalanced) social relations, that is, to interpret it in terms of its unequal genetic material (racial subjugation, sexual domination, capital reproduction, knowledge legitimation, and many other power differentials). The "same boat argument," when connected to the ongoing Covid-19 pandemic, is only going to work, in other words, it could only be philosophically legitimate, once all intersectional differentials have been materially corrected and socially transcended. Therefore, an Afrocentric philosophical pathogenomics, employed to detect and possibly cure those disciplinary resistances, patriarchal virulence factors, and racist infections still active in our professional body, would also be a useful tool to neutralise the seductive powers of those conspicuous Eurocentric investments unhealthily dominating theoretical analyses and institutional discussions about the current SARS-CoV-2 pandemic.

\section{References}

Agamben, G. 1998. Homo Sacer. Sovereign Power and Bare Life, translated by Daniel HellerRoazen. Stanford: Stanford University Press.

Agamben, G. 2020. A che punto siamo? L'epidemia come politica. Macerata: Quodlibet.

Agamben, G. 2020a. https://aphelis.net/agamben-coronavirus-pandemic-interventions/. Accessed December 10, 2020.

Agamben, G. 2020b. http://positionswebsite.org/giorgio-agamben-the-state-of-exceptionprovoked-by-an-unmotivated-emergency/. Accessed December 10, 2020.

Agamben, G. 2020c. http://autonomies.org/2020/03/giorgio-agamben-normalising-the-state-ofexception-under-the-covid-19-epidemic/. Accessed December 10, 2020.

Agamben, G. 2020d. https://itself.blog/2020/05/02/giorgio-agamben-medicine-as-religion/. Accessed December 10, 2020.

Agamben, G. 2020e. https://d-dean.medium.com/biosecurity-and-politics-giorgio-agamben396f9ab3b6f4. Accessed December 10, 2020.

Agamben, G. 2020f. https://itself.blog/2020/04/15/giorgio-agamben-a-question/. Accessed December 10, 2020.

Agamben, G. 2020g. https://d-dean.medium.com/requiem-for-the-students-giorgio-agamben866670c11642. Accessed December 10, 2020.

Asante, M. K. 2017. "The Philosophy of Afrocentricity." In The Palgrave Handbook of African Philosophy, edited by Adeshina Afolayan and Toyin Falola. New York: Palgrave Macmillan, 231-244. https://doi.org/10.1057/978-1-137-59291-0_16.

Gqola, P. D. 2009. "The Difficult Task of Normalizing Freedom: Spectacular Masculinities, Ndebele's Literary/Cultural Commentary and Post-Apartheid Life." English in Africa 36 (1): 61-76. https://doi.org/10.4314/eia.v36i1.42868. 
Gqola, P. D. 2009a. "Pushing out from the Centre: (Black) Feminist Imagination, Redefined Politics and Emergent Trends in South Africa Poetry." XCP: Cross Cultural Poetics 21 (22): $1-19$.

Gqola, P. D. 2016. "Intimate Foreigners or Violent Neighbours? Thinking Masculinity and Post-apartheid Xenophobic Violence through film.” Agenda 30 (2): 64-74. https://doi.org/10.1080/10130950.2016.1215625.

Irigaray, L. 1993. An Ethics of Sexual Difference, translated by Carolyn Burke and Gillian C. Gill. Ithaca: Cornell University Press.

Irigaray, L. 1999. The Forgetting of Air in Martin Heidegger, translated by Mary Beth Mader. London: The Athlone Press.

Kidd, I. J., and M. Ratcliffe, 2020. "Welcome to Covidworld. Trying to understand Covidworld, our new altered reality where accepted norms do not apply." The Critic November 2020. Accessed December 10, 2020. https://thecritic.co.uk/issues/november2020/welcome-to-covidworld/.

MacLellan, M. 2013. "Marx's Vampires: An Althusserian Critique.” Rethinking Marxism 25 (4): 549-565. https://doi.org/10.1080/08935696.2013.842699.

Mignolo, W. D. 2017. "The Advent of Black Thinkers and the Limits of Continental Philosophy." In The Palgrave Handbook of African Philosophy, edited by Adeshina Afolayan and Toyin Falola. New York: Palgrave Macmillan, 287-301. https://doi.org/10.1057/978-1-137-59291-0_19.

More, M. P. 2002. "African Renaissance: The Politics of Return.” African Journal of Political Science 7 (2): 61-80. https://doi.org/10.4314/ajps.v7i2.27331.

More, M. P. 2009. "Black Solidarity. A Philosophical Defense." Theoria: A Journal of Social and Political Theory 56 (120): 20-43. https://doi.org/10.3167/th.2009.5612003.

Neocleous, M. 2003. “The Political Economy of the Dead: Marx's Vampires.” History of Political Thought 24 (4): 668-684.

Outlaw, L. T. (Jr.). 1996. On Race and Philosophy. New York-London: Routledge.

Outlaw, L. T. (Jr.). 2017. “'Black’ Philosophy, 'African’ Philosophy, 'Africana' Philosophy: Transnational Deconstructive and Reconstructive Renovations in 'Philosophy'." In The Palgrave Handbook of African Philosophy, edited by Adeshina Afolayan and Toyin Falola. New York: Palgrave Macmillan, 245-267. https://doi.org/10.1057/978-1-13759291-0_17. 


\begin{abstract}
Alloggio
West, C. 1988. "Marxist Theory and the Specificity of Afro-American Oppression." In Marxism and the Interpretation of Culture, edited by Cary Nelson and Lawrence Grossber. Urbana/Chicago: University of Illinois Press, 17-33. https://doi.org/10.1007/978-1-34919059-1_2.
\end{abstract}

World Health Organisation. 2020. Global Report on the Epidemiology and Burden of Sepsis: Current Evidence, Identifying Gaps and Future Directions, Geneva 2020. Accessed December 10, 2020.

https://apps.who.int/iris/bitstream/handle/10665/334216/9789240010789-eng.pdf.

Žižek, S. 2020. Pandemic! Covid-19 Shakes the World. New York-London: OR Books. https://doi.org/10.2307/j.ctv16t6n4q. 